\title{
Profile and competences of Spanish industrial engineers in the European Higher Education Area (EHEA)
}

\author{
Juan A. Marin-Garcia ${ }^{1}$; Jose P. Garcia-Sabater ${ }^{1}$; Cristóbal Miralles ${ }^{1}$; Alejandro Rodríguez
} Villalobos ${ }^{2}$

${ }^{1}$ ROGLE-Departamento de Organización de Empresas. Universidad Politécnica de V alencia (SPAIN);

${ }^{2}$ Departamento de Organización de Empresas. Universidad Politécnica de Valencia (SPAIN)

jamarin@omp.upv.es;jpgarcia@omp.upv.es; cmiralles@,omp.upv.es; arodriguez@omp.upv.es

Received September 2008

Accepted November 2008

Abstract: The aim of this document is to develop a clear definition of the role of the industrial engineer. This is important in the Spanish context, where the engineer curricula are evolved in a different way than in other countries, due to the role developed by the Professional Associations of Engineers and Technical Engineers. To this end we identify here the professional profiles to be expected of those graduating from such courses, the sectors where they are most likely to be recruited, and the context within which industrial engineers are employed. We deal with meanings and proposals for Industrial Engineers within a European context, drawing information from the academic debate which has been launched in a number of scientific publications. The text summarizes our personal reflections, which are integrated within a proposal for action intended as an additional contribution to the critical debate as to the situation, rather than a final response.

Keywords: industrial engineer, curricula, education, university reform

\section{Introduction}

Globalisation is one of the contextual factors most strongly influencing the way in which we understand and design today's business processes (Figuera Figuera, 2007; Gallwey, 1992). It is a movement, which also affects higher education, 
where national approaches are converging towards a set of models, which are gradually taking root across our neighbouring countries (Dym, 2008; Engwall, 2007; Schaefer, Panchal, Choi, \& Mistree, 2008). In Spain, new curricula are being drawn up in response to the need to deal with the challenge of European Convergence. In practical terms, however, we may find that in defining each qualification, rather than looking to the future we concern ourselves with the immediate present, in an attempt to reproduce the structures of qualifications similar to those previously in existence. In fact, there has not yet been any clear statement (or at least none that we know) as to as to whether the profession is to be developed as a specialisation of the Industrial Technology Engineering degree, or whether the approach will be to establish a specific Industrial Engineering graduate qualification.

We feel that the first step to be taken is to clarify what Industrial Engineering (as currently referred to in Spain as 'Ingeniería de Organización') means. In other words, to define the tasks or activities required by companies of the individuals whom they recruit to positions which could correspond to the profile which we would understand to be that of the Industrial Engineer. This can then serve as the basis for establishing the professional skills required in order to perform these tasks. We would then to be capable of devising and presenting a product which is attractive for society, in particular families and future students (immediate clients), and of course for companies. It must be remembered that successful courses are those which succeed in maintaining good levels of employment, with high rates of enrolment.

Nonetheless, curriculum committees in Spain may follow a rather different approach and begin directly by drawing up the study plan, identifying subjects and credits and bypassing all the steps set out in the previous paragraph, in the belief that they have already been completed. It is true that this issue has been discussed over recent years and that some information has been put down in writing. Some considerable work still remains to be done, however, including a need to set out the knowledge, skills and attitudes of today's engineers (Bankel et al., 2003). In Spain, with two noteworthy exceptions (ANECA, 2005; Figuera Figuera, 2007), the information presented regarding the national proposals is, in our judgement, lacking, probably biased, and has been disseminated by means of highly limited channels. 
The aim of this document is to develop a clear definition of industrial engineering. To this end we identify here the professional profiles to be expected of those graduating from such courses, specifying the technology employed, the problems treated and the population served by the industrial engineers (Ferguson, 2006; Thompson, 1967). We deal with meanings and proposals for Industrial Engineers within a European context, drawing information from the academic debate which has been launched in a number of scientific publications (using "Engineering and industrial and education" as keyword in Web Of Science, Science Direct and EBSCO Business Source Premier databases). We also draw on professional recruitment figures (De Miguel Fernández, 1995; Martínez Costa, Calvet Puig, Pons Peregort, \& Tura Solvas, 2007).

\section{Function of industrial engineers}

We believe it is important to define the function and skills required of an industrial engineer (Elsayed, 1999). It would perhaps first be appropriate to recall the origins of this branch of engineering. There can be no doubt as to the identity of the first professional industrial engineers, namely such key figures as F. W. Taylor and the Gilberths (Elsayed, 1999). New needs were progressively added to the work performed by these pioneering individuals over the course of the last century, including, for example, management, operational research, organisational behaviour, technology management, operational management and quality management (Elsayed, 1999). It may be that the paradigm represented by Taylorism or Fordism a century ago is now represented by lean manufacturing or flexible production (Holweg, 2007; Vazquez-Bustelo \& Avella, 2006). Lean manufacturing thus represents the underlying task of industrial engineers at today's companies (Gallwey, 1992). This task must be complemented by certain aspects of technological knowledge and marketing but above all, and increasingly, by service, financial knowledge and familiarity with corporate social responsibility (including the environment) (Gallo, 2004; Maffioli \& Augusti, 2003; Porter \& Kramer, 2006). The task of industrial engineers has traditionally been associated with manufacturing processes. However, it has proved useful to apply their knowledge to other sectors, such as the public sector and services of all kinds (health, transport, commercial, financial, etc.) (ANECA, 2005; Fliedner \& Mathieson, 2007; Gallwey, 1992; Maffioli \& Augusti, 2003). 
Ultimately, industrial engineers are required in any situation where there is a need to employ limited resources in the most efficient manner possible (Gallwey, 1992). This need today applies to almost all business activities within the western world. The main reason for this is the globalisation of markets and increased competition from products and services relocated to countries with low wage levels (Ferguson, 2006; Gallwey, 1992; Yannou \& Bigand, 2004). The situation is heightened by the fact that companies in countries competing only on the basis of cost are succeeding in increasing their productivity while also achieving technological advances allowing them to offer higher quality and even innovative products and services (Yannou \& Bigand, 2004). Within this context, one way to establish a certain competitive edge is to provide society with industrial engineers who are capable of working within complex and inter-dependent environments, exploiting current technology and channelling the energy of the individuals for whom they are responsible (Markes, 2006; Ratchev, Blackwell, \& Bonney, 2002).

The industrial engineer must be, above all, an engineer. That is, as he is conceived by the Institute of Industrial Engineering or the British Engineering Council, the engineer must be capable of analysing, modelling, designing, implementing and improving complex systems made up of people, materials, money, information, machines, technology and energy, for the purpose of offering products and services in the least time and with the greatest productivity, quality, reliability and efficiency possible (ABET \& EUR-ACE, 2007; Chen, Jiang, \& Hsu, 2005; Elsayed, 1999; Gallwey, 1992; Maffioli \& Augusti, 2003; Mummolo, 2007; Ratchev et al., 2002; Salvendy, 2001; Womack \& Jones, 1996; Zandin \& Maynard, 2005).

However, the industrial engineer is also a professional with a solid background in mathematics, quantitative methods and statistics, who knows what operations management tools consist of, what they are for and how they are used in a company in helping to provide products and services in the least amount of time and with the greatest productivity, quality, reliability and efficiency possible. He is also capable of diagnosing problems, analysing them, suggesting possibilities for improvement and deciding which of the operations management tools is best to use/not to use in his/her area of responsibility.

Without being exhaustive and in order to clarify what we mean by operations management tools we will highlight the following: knowledge management, process standardisation, visual management, personnel management, strategic 
management of the operations area, cost accounting, lean office, JIT, KANBAN, TPM, TQM, customer and supplier relations, integrated design with manufacturing, selection of the appropriate manufacturing technology, one-piece-flow, work balancing, SMED, industrial housekeeping... All these tools are focused in improve processes, but We would like to stress that our definition of operations includes both the manufacturing and assembly as providing a service, either logistically or any other kind.

In order to decide which tool to use, he/she must be able to evaluate the strategic priorities of his company, the key indicators, the available resources, the expected profits and costs, the sector's situation and the technological limitations of the products/services that the company offers, the processes with which they are produced and the corporate social responsibility.

Once the decision is made, he/she is able to collaborate in the implementation and follow-up of the suggested actions, preparing the protocols, calculations, plans, programs, simulations, etc., required for this. He will also have an important role in leading and motivating the people that must collaborate in the implementation.

\section{Difference from other forms of engineering}

The industrial branch is made up of four basic engineering fields: mechanical, electrical, chemical and industrial engineering (Elsayed, 1999). The Spanish university system proposes to extend this to a catalogue of 10 engineering disciplines (Mechanical, Materials, Electrical, Electronic and Automatic, Chemical, Energy, Industrial Organisation, Industrial and Product Design, Industrial Technology, Textile). Of these, only four (Mechanical, Electrical, Chemical and Industrial Technology) has a legally established framework of professional attributes covered by a Professional Association. Taking as our premise the undeniable fact that all forms of engineering within the industrial branch have considerable overlaps, it is equally true that there are considerable differences. The emphasis of what is referred to in Spain as Industrial Engineering (called "Ingenieros de Organización") is thus more strongly placed on the human aspects and the economic viability of the proposals designed than on their technical viability, which would be the ambit of Mechanical Engineers or Industrial Technology Engineers (called "Ingenieros en Tecnologías Industriales") (Gallwey, 1992). To give another example, the problem of maintenance for an Industrial 
Engineer involves finding models to optimise the productive time of machines, while for a Mechanical Engineer it would involve designing parts to reduce wear and tear (Gallwey, 1992). Ultimately, the functions of an Industrial Technology Engineer connected with the profession governed by the Professional Association are almost exclusively those of an Industrial Facility Project Engineer. In other words, the individual who design and executes all manner of facilities and operations, with complete authority to sign off all manner of related drafts or documents and to manage and execute construction work and installations (Royal Decree 1665, of 25 October 1991; Decree of 18 September 1935; Spanish Supreme Court, in administrative litigation appeal number 91/2003).

One further distinguishing characteristic is that an Industrial Engineer requires much broader and more substantial grounding in mathematics, economics, management, service processes, information technology and statistics than do other branches of engineering. Programming skills are also required (VBA or Java) in order to automate the calculation of customised algorithms, since there is unlikely to be any commercial software available which could appropriately cover all needs. Mechanical and Industrial Technology Engineers, meanwhile, require a stronger background in physics, while Energy Engineers need greater knowledge of chemistry.

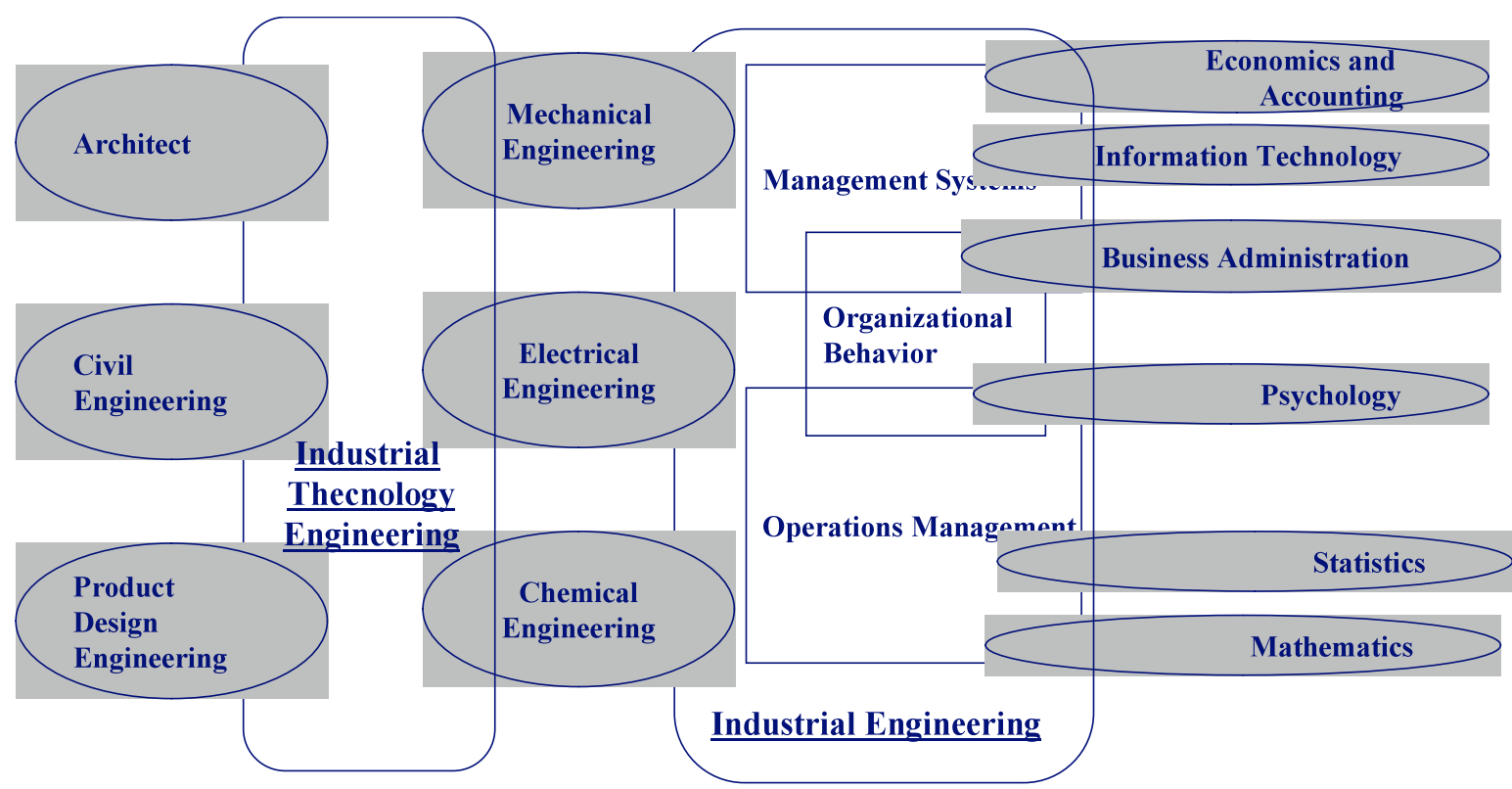

Figure 1. "Relationships between subjects". 
In figure 1 we show some of the relationships between disciplines (Gallwey, 1992; Salvendy, 2001; Zandin \& Maynard, 2005). We focus on the most related branches (Industrial Engineering and Industrial Technology Engineering) and point up the bridge that link both of them, based in mechanical, electrical and chemical knowledge. We show also the differences: Industrial Technology Engineering is more related to design and facilities building whereas Industrial Engineering is more associated to economics, information technology, business administration, psychology, statistics and mathematics. The three main specific blocks of the industrial engineering could be probably the operations management, the management system and the organizational behaviour. These blocks complement the basic block of engineering skills.

\section{Professional profile of Industrial Engineering}

A professional profile is the set of skills (knowledge, abilities and attitudes) required in order to practise a profession within a given sphere (Amini \& Rahman, 2008; ANECA, 2005). We can divide the skills required by an Industrial Engineer into 4 categories (Ferguson, 2006):

- General skills required by any manager. This would cover many crossfunctional skills: interpersonal communications, teamwork and leadership (Dym, 2006; Maffioli \& Augusti, 2003; Teixeira, Ferreira, Silva, \& Flores, 2007). But also the ability to formulate a problem, to model it and to think up solutions; to develop the creativity of colleagues; to recruit individuals, to motivate them and assess their progress; to negotiate and assess risks; to organise information flows; to understand strategy, marketing and economic concepts (Bankel et al., 2003; Chen et al., 2005; Ferguson, 2006; Yannou \& Bigand, 2004).

- General scientific engineering knowledge. In other words, complete familiarity with the technical idiom in order to understand the complex systems referred to in the definition of an engineer. Such knowledge must also allow them to communicate with other professionals from the industrial branch forming part of a team. This knowledge would include physics, chemistry, industrial technology (Elsayed, 1999), quality management and corporate social responsibility (Gallo, 2004; Porter \& Kramer, 2006; Sheppard, Colby, Macatangay, \& Sullivan, 2006). 
- The specific skills of Industrial Engineers which set them apart from other engineers. Highly developed knowledge and skills in mathematics, multivariant industrial statistics, data mining, industrial economics, continuous improvement, distribution of assembly lines, production programming, reduction of changeover times, optimisation of inventories, workstation analysis, knowledge management, Six Sigma, activity-based costing, multicriteria decisions, productive maintenance, supply chain management, simulation... (Elsayed, 1999; Fliedner \& Mathieson, 2007; Gallwey, 1992; Maskell, 2000; Yannou \& Bigand, 2004)

- Knowledge and skills specific to the sector where the graduate is ultimately employed (Ferguson, 2006).

Almost all the above skills are connected with knowledge and abilities. They must also be combined with the attitudes sought in industrial engineers, such as continuous learning and the ability to question everything, including traditional practices (Gallwey, 1992; Markes, 2006).

Various lists have been drawn up of the skills connected with engineering (ABET \& EUR-ACE, 2007; Amini \& Rahman, 2008; ANECA, 2005; Bankel et al., 2003; Maffioli \& Augusti, 2003; Markes, 2006; Order CIN/2134/2008 of 3 july 2008, 2008). The common ground which they all share is considerable. However, they describe skills in very general terms (Maffioli \& Augusti, 2003). In fact, they all describe a profile which would be valid for any manager or engineer, and we have not found any published list of the specific skills of an Industrial Engineer offering a sufficient level of detail in order to serve as the focus for the design of the subjects which are to make up the curriculum. Therefore, we have worked on a proposal, which is summarized in table 1.a to $1 . d$ (general competences) and 2.a to 2.e (specific competences). 


\begin{tabular}{|l|l|}
\hline \multirow{y}{*}{ Basic scientific } & $\begin{array}{l}\text { Know and use appropriately the mathematical language, numeric analysis, } \\
\text { numeric calculation methods and linear algebra and their application to company } \\
\text { management and operations management, especially quantitative methods / } \\
\text { operative research. }\end{array}$ \\
\cline { 2 - 3 } competences & $\begin{array}{l}\text { Know the terminology, principles and concepts of general physics and mechanics } \\
\text { and their application in operations management. }\end{array}$ \\
\cline { 2 - 3 } & $\begin{array}{l}\text { Know the terminology and appropriate notation of chemistry and material } \\
\text { structure and their applications to the transformation of products in industrial } \\
\text { processes. }\end{array}$ \\
\cline { 2 - 3 } & $\begin{array}{l}\text { Know the concepts of energy technology that condition the manufacturing of } \\
\text { products and services that respect the environment and calculate the energy and } \\
\text { environmental impact of manufacturing products and services. }\end{array}$ \\
\cline { 2 - 3 } & $\begin{array}{l}\text { Know and apply the fundamentals of fluids and hydraulic machine installations for } \\
\text { industrial processes and services. }\end{array}$ \\
\cline { 2 - 3 } & $\begin{array}{l}\text { Know the terminology and appropriate notation of statistics and bivariate and } \\
\text { multivariate statistical analysis, and use the principles and concepts of statistics to } \\
\text { solve problems of business management and operations management using the } \\
\text { ability to obtain data to confirm hypothesis. }\end{array}$ \\
\hline
\end{tabular}

Table 1a. "General competences".

\begin{tabular}{|c|c|}
\hline \multirow{5}{*}{$\begin{array}{l}\text { Basic } \\
\text { technology } \\
\text { competences }\end{array}$} & $\begin{array}{l}\text { Know the principles and concepts of electricity, electromagnetism and field and } \\
\text { wave theory and their application to industrial processes. Know the basic principles } \\
\text { and concepts of electrical machines, their functioning principles and their different } \\
\text { types and variations. Know the basic principles and concepts of electric } \\
\text { magnitudes and the fundamentals of electric circuits used in industrial processes } \\
\text { and services. }\end{array}$ \\
\hline & $\begin{array}{l}\text { Know and apply the principles and concepts of the structure and properties of the } \\
\text { materials and mechanisms in order to modify their properties by joining, shaping, } \\
\text { filling, perforating or combining substances for their industrial application. }\end{array}$ \\
\hline & $\begin{array}{l}\text { Know the basic fundamentals of computer science and computer programming and } \\
\text { different programming languages. Develop applications based on computer } \\
\text { languages to resolve problems of company and operations management. }\end{array}$ \\
\hline & $\begin{array}{l}\text { Know the basic principles and concepts of the components, electronic devices and } \\
\text { control systems and their industrial and service applications. Know the electronic, } \\
\text { mechanical or other alternatives for capturing, locating and communicating data } \\
\text { related to company management and operations management. Know alternatives } \\
\text { for setting up networks between plants or between companies, distributed systems } \\
\text { and data flows. Design and select the suitable control devices for the automation } \\
\text { of industrial processes or to install data collection systems. }\end{array}$ \\
\hline & $\begin{array}{l}\text { Know and apply the basic principles and concepts of mechanical, magnetic and } \\
\text { pneumatic systems and the calculation of machine elements and their industrial } \\
\text { applications for operating, positioning or transporting materials or components. } \\
\text { Know and select the operations, manual and automatic processes for the } \\
\text { processing, assembly and disassembly of pieces and components. Select the } \\
\text { appropriate machines and technology for the company processes (FMS, } \\
\text { Robotisation, etc.). Management of Advanced Manufacturing Systems. }\end{array}$ \\
\hline
\end{tabular}

Table 1b. "General competences".

\begin{tabular}{|l|l|}
\hline \multirow{4}{*}{$\begin{array}{c}\text { Basic business } \\
\text { competences }\end{array}$} & $\begin{array}{l}\text { Know and apply the basic laws, regulations and rules related to industrial } \\
\text { activities, including security and environmental regulations that affect the business } \\
\text { and ergonomics processes. Draw up plans for occupational hazard prevention. }\end{array}$ \\
\cline { 2 - 2 } & $\begin{array}{l}\text { Know the basic company principles (economy, strategy, leadership functions, } \\
\text { commercial management, operations management, human resources } \\
\text { management, costs...). }\end{array}$ \\
\cline { 2 - 2 } & $\begin{array}{l}\text { Draw up and apply internal company policies that reinforce and specify the } \\
\text { Corporate Social Responsibility. }\end{array}$ \\
\hline
\end{tabular}

Table 1c. "General competences". 


\begin{tabular}{|c|c|}
\hline \multirow{12}{*}{$\begin{array}{l}\text { Miscellaneous } \\
\text { competences }\end{array}$} & $\begin{array}{l}\text { Know the basic principles and concepts of industrial pollution, the environmental } \\
\text { impact of the industrial activities and the treatment, recycling and management of } \\
\text { industrial and urban waste. }\end{array}$ \\
\hline & $\begin{array}{l}\text { Know the principles of the techniques of graphic representation and computer } \\
\text { assisted design and use the computer applications related to computer assisted } \\
\text { design (CAD-CAM-CAE). Appropriately interpret plans. }\end{array}$ \\
\hline & $\begin{array}{l}\text { Perform measurements, calculations, evaluations, appraisals, inspections, studies, } \\
\text { reports, plans and other analogous jobs related to business management and } \\
\text { operations management. }\end{array}$ \\
\hline & $\begin{array}{l}\text { Be able to work and communicate efficiently in international contexts (e-mail, } \\
\text { forums, chats, reports, wikis, video conferences, telephone, elaboration of visual } \\
\text { aids for presentations, preparation of diagrams and outlines, collaborative web } \\
\text { pages...). Create and manage efficiently and with high performance extensive } \\
\text { documents (reports, dossiers and posters) and quality presentations adapted to } \\
\text { the potential audience, using the ITCs. }\end{array}$ \\
\hline & Collaborate in the management of knowledge. \\
\hline & $\begin{array}{l}\text { Work on a team, taking on different roles and responsibilities (group leader, } \\
\text { reporter, facilitator, spokesperson for the group, or any other that is assigned). } \\
\text { Direct and participate efficiently in meetings. Be a leader. }\end{array}$ \\
\hline & $\begin{array}{l}\text { Social, ethical and environmental commitment to the development of engineering } \\
\text { or architectonic solutions that are compatible, sustainable and always } \\
\text { synchronised with the reality of the human and natural environment. }\end{array}$ \\
\hline & $\begin{array}{l}\text { Be capable of interpersonal communication, comprehensible reading and active } \\
\text { listening. }\end{array}$ \\
\hline & $\begin{array}{l}\text { Suggest alternatives for solving detected problems and encourage creativity in his } \\
\text { work environment. Initiative and enterprising spirit. }\end{array}$ \\
\hline & $\begin{array}{l}\text { Adequately formulate research questions and find literature specific to a problem } \\
\text { in academic journals. }\end{array}$ \\
\hline & $\begin{array}{l}\text { Adequately use the basic office automation applications. Design and efficiently use } \\
\text { spreadsheets, productivity and communication tools and management of } \\
\text { collaborative platforms, document and portals management. }\end{array}$ \\
\hline & $\begin{array}{l}\text { Aptitude for the methodology and skills of efficient self-learning for the adaptation } \\
\text { and updating of new knowledge and scientific advances throughout his lifetime, as } \\
\text { well as the evolution of the needs, in order to adopt an innovative and creative } \\
\text { attitude in the exercise of business management and operations management. }\end{array}$ \\
\hline
\end{tabular}

Table 1d. "General competences".

\begin{tabular}{|l|l|}
\hline \multirow{4}{*}{$\begin{array}{l}\text { Strategy and } \\
\text { management }\end{array}$} & $\begin{array}{l}\text { Basic concepts of accounting and finances. Interpretation of balance sheets and } \\
\text { calculation of ratios that aid in the making of business decisions. Managing the } \\
\text { company's financial resources. Investment analysis. }\end{array}$ \\
\cline { 2 - 3 } & $\begin{array}{l}\text { Know and apply the principles, concepts and procedures of calculating product and } \\
\text { service costs. }\end{array}$ \\
\cline { 2 - 3 } & $\begin{array}{l}\text { Measure and compare the company's performance selecting the suitable } \\
\text { indicators. }\end{array}$ \\
\cline { 2 - 3 } & $\begin{array}{l}\text { Be able to make decisions in ambiguous or uncertain situations where there may } \\
\text { be different criteria in play. }\end{array}$ \\
\cline { 2 - 3 } & $\begin{array}{l}\text { Define the most appropriate vision for the company and the strategy best adapted } \\
\text { to the conditions of the competitive environment. Formulate objectives for the } \\
\text { company and establish the plans to achieve them. }\end{array}$ \\
\hline Lead the processes of change in the company. \\
\cline { 2 - 2 } \\
$\begin{array}{l}\text { Create strategies and human resources policies and manage the human resource } \\
\text { functions as the person in charge of operations: description of posts, training, } \\
\text { performance evaluation, rewards and involvement of the staff. }\end{array}$ \\
\hline
\end{tabular}

Table 2a. "Specific competences of Industrial Engineering".

\begin{tabular}{|c|l|}
\hline \multirow{2}{*}{$\begin{array}{c}\text { Information } \\
\text { management }\end{array}$} & \begin{tabular}{l} 
Manage data storage and recovery. \\
\cline { 2 - 2 }
\end{tabular} \\
$\begin{array}{l}\text { Develop and deploy information systems to support the business decisions. Model } \\
\text { information management and the company (CIM, MRPII, ERP, SCM, etc.) }\end{array}$ \\
\hline
\end{tabular}

Table 2b. "Specific competences of Industrial Engineering". 


\begin{tabular}{|l|l|}
\hline \multirow{5}{*}{$\begin{array}{c}\text { Process design } \\
\text { and planning }\end{array}$} & $\begin{array}{l}\text { Identification, design, implementation and follow-up of the management and } \\
\text { operating processes (operations in industrial and service companies). Design the } \\
\text { structure of the company's business processes and company relations. Establish } \\
\text { relationships with customers and suppliers. }\end{array}$ \\
\cline { 2 - 3 } & $\begin{array}{l}\text { Choose the best work organisation (work study) } \\
\text { the delivery of products/services to the customers. }\end{array}$ \\
\cline { 2 - 3 } & $\begin{array}{l}\text { Plan the acquisition of materials; establish the guidelines to transform them into } \\
\text { products/services. }\end{array}$ \\
\cline { 2 - 3 } & $\begin{array}{l}\text { Management of the company's physical resources (selection, dimensioning, } \\
\text { capacity, location, maintenance and evaluation of its efficiency). }\end{array}$ \\
\cline { 2 - 2 } & $\begin{array}{l}\text { Forecast, plan, program and manage the production and delivery of products and } \\
\text { services by the company. }\end{array}$ \\
\cline { 2 - 2 } & $\begin{array}{l}\text { Select the most appropriate materials and components to use in the company's } \\
\text { processes and assign resources. }\end{array}$ \\
\hline
\end{tabular}

Table 2c. "Specific competences of Industrial Engineering".

\begin{tabular}{|c|l|}
\hline \multirow{5}{*}{$\begin{array}{c}\text { Process } \\
\text { Improvement }\end{array}$} & $\begin{array}{l}\text { Draw up quality plans (model EFQM, ISO-9000, etc.) and carry out quality } \\
\text { assessments (on products/services and processes). }\end{array}$ \\
\cline { 2 - 3 } & $\begin{array}{l}\text { Guarantee the quality of the products/services offered to the customers and the } \\
\text { related processes. }\end{array}$ \\
\cline { 2 - 3 } & $\begin{array}{l}\text { Formulate problems, model them, solve them and/or simulate processes. Optimise } \\
\text { processes using the algorithms or appropriate procedures. }\end{array}$ \\
\cline { 2 - 3 } & $\begin{array}{l}\text { Analyse a user's requirements by describing a product or need in the form of } \\
\text { strategy and the customers' expectations, and prepare them for production and } \\
\text { recycling. Identify and develop business initiatives. Identify customers' needs and } \\
\text { supervise changes in the expectations in the customers or the markets. }\end{array}$ \\
\hline & $\begin{array}{l}\text { Improve processes, products and systems. Identify, suggest and promote } \\
\text { improvements that reduce the costs, the resources used and the manufacturing or } \\
\text { delivery period, or that increase the company's efficiency, quality, flexibility or } \\
\text { innovation, respecting the environment and the corporate social responsibility. }\end{array}$ \\
\hline $\begin{array}{l}\text { Prepare, carry out and analyse the design of experiments in order to improve the } \\
\text { products and processes. Use multivariate statistics to interpret data. }\end{array}$ \\
\hline
\end{tabular}

Table 2d. "Specific competences of Industrial Engineering".

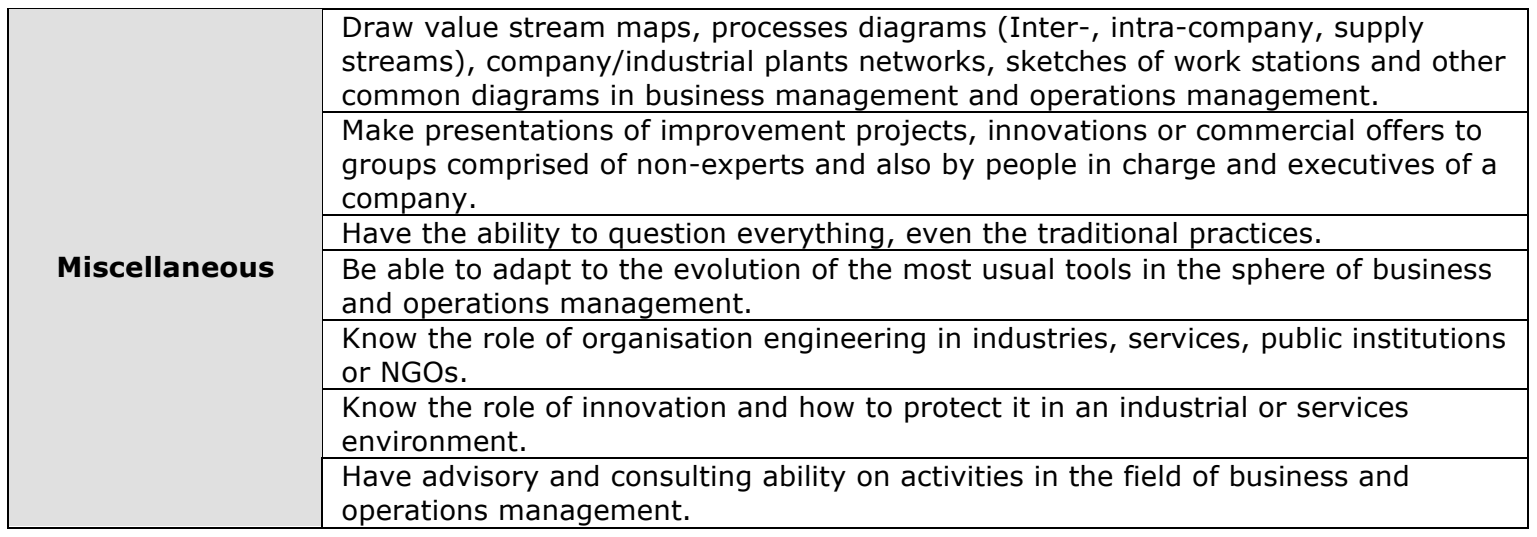

Table 2e. "Specific competences of Industrial Engineering". 
In table 3 we summarize the domain of Industrial Engineering based on the technology employed, the problems treated and the population served (Salvendy, 2001; Thompson, 1967).

\begin{tabular}{|c|c|c|}
\hline Technology employed & Problems treated & Population served \\
\hline $\begin{array}{l}\text { - Simulation and modelling } \\
\text { - Information technology } \\
\text { - Management Tools } \\
\text { - Lean Manufacturing Tools } \\
\circ \quad \text { One piece flow tools } \\
\text { - Quality tools } \\
\text { - Maintenance tools } \\
\text { - Human Resource } \\
\text { Management tools }\end{array}$ & $\begin{array}{l}\text { - Overproduction } \\
\text { - Excess transportation or } \\
\text { motion } \\
\text { - Excess inventory } \\
\text { - Excess processing } \\
\text { - Waiting and waste of } \\
\text { customer time } \\
\text { - Correction } \\
\text { - The waste of untapped } \\
\text { - human potential } \\
\text { - The waste of inappropriate } \\
\text { - Wystems } \\
\text { - } \text { masted energy, water and } \\
\text { - Service and office wastes } \\
\text { custe of defecting } \\
\text { customers }\end{array}$ & $\begin{array}{ll} & \text { Industry } \\
\text { - } & \text { Public Sector } \\
\text { - } & \text { Services } \\
\circ & \text { Logistic } \\
\circ & \text { Health } \\
\circ & \text { Transport } \\
\circ & \text { Commercial } \\
\circ & \text { Financial } \\
\circ & \text { Etc. }\end{array}$ \\
\hline
\end{tabular}

Table 3. "Domain of Industrial Engineering".

\section{Conclusions}

An Industrial Engineering qualification is essential for a country concerned with maintaining or reviving the competitive edge of its companies. It would be reasonable to consider that the intensification of Organisation within the Industrial Technology Engineering qualification and the second-cycle course established by Royal Decree 1401/1992 served as a pilot study for an Industrial Engineering qualification, and that this works well and is attractive to companies. Considering the number of engineers initially trained within other disciplines and who have had to convert to being Industrial Engineers ("Ingenieros de Organización" in spanish) because of their professional activity, the demand for this qualification is truly striking.

Nonetheless, there is a certain tendency to block the creation of an Industrial Engineering course which is genuinely different and separate from other engineering disciplines (in particular Industrial Technology). Some of the arguments invoked in support of this position are reasonable. Others, however, are clearly unfounded if we consider the circumstances and observations from a number of regions. It may be that in some of Spain's Autonomous Regions, given the nature of their business fabric, it may not make sense to offer an Industrial 
Engineering qualification, and it may be more efficient to offer a general catch-all Engineering degree. In other regions, however, it is essential that we produce Industrial Engineering graduates. We therefore believe that the option of a general Engineering course with sparse knowledge of organisation would be the worst of the choices considered. It is our position that the best approach would be to provide a genuine specialist Industrial Engineering course at those universities which uncover a demand for this within their social context, and to select the option of Industrial Technology Engineering (or any other engineering discipline more suited to the context) in addition to a Master's in those locations where the business circumstances do not justify a demand for this specialist graduate qualification.

\section{Acknowledgments}

Acknowledgements: We would like to thank the Grupo de Innovación en la Evaluación para la Mejora del Aprendizaje Activo (Innovation in Assessment for Enhanced Active Learning Group) of Universidad Politecnica of Valencia for their help financing and preparing this paper, and the $R+D+i$ Linguistic Assistance Office at the Universidad Politecnica of Valencia for their help in translating this paper.

\section{References}

ABET \& EUR-ACE (2007). Criteria for accrediting engineering programs.

Amini, F., \& Rahman, S. (2008). A systematic and structured outcome assessment plan for a new engineering program. International Journal of Engineering Education, 24(1), 185-198.

ANECA (2005). Libro blanco de titulaciones de grado de Ingeniería de la Rama Industrial: capítulo $V$ Ingeniero de Organización Industrial http://www.aneca.es/activin/activin_conver_LLBB_indus.asp (Last Accesed 23nov-2007).

Bankel, J., Berggren, K. F., Blom, K., Crawley, E. F., Wiklund, I., \& Östlund, S. (2003). The CDIO syllabus: a comparative study of expected student proficiency. European Journal of Engineering Education, 28(3), 297-315. 
Chen, C., Jiang, B. C., \& Hsu, K. (2005). An empirical study of industrial engineering and management curriculum reform in fostering students' creativity. European Journal of Engineering Education, 30(2), 191-202.

De Miguel Fernández, E. (1995). Un modelo para la especialización de los ingenieros industriales de la Comunidad Valenciana. Paper presented at the $V$ Congreso Nacional de Economía

Dym, C. L. (2006). Engineering design: So much to learn. International Journal of Engineering Education, 22(3), 422-428.

Dym, C. L. (2008). Educating engineers for a flat world. International Journal of Engineering Education, 24(2), 214-220.

Elsayed, E. A. (1999). Industrial Engineering Education: A Prospective. European Journal of Engineering Education, 24(4), 415-421.

Engwall, L. (2007). The anatomy of management education. Scandinavian Journal of Management, 23(1), 4-35.

Ferguson, C. (2006). Defining the Australian mechanical engineer. European Journal of Engineering Education, 31(4), 471-485.

Figuera Figuera, J. R. (2007). Análisis del pasado de la Ingeniería de Organización en España para mantener su competitividad en el futuro. Paper presented at the International Conference on Industrial Engineering \& Industrial Management - CIO (pp. 931-940). Madrid.

Fliedner, G. \& Mathieson, K. (2007). Learning Lean: A Survey of Industry Lean Needs.

Gallo, G. (2004). Operations Research: Responsibility, Sharing and Cooperation. European Journal of Operational Research, 153, 468-476.

Gallwey, T. J. (1992). Europe Needs Industrial Engineering Degrees in Order to Enhance Its Competitiveness. European Journal of Engineering Education, 17(1), 51-57. 
Holweg, M. (2007). The genealogy of lean production. Journal of Operations Management, 25(2), 420-437.

Maffioli, F. \& Augusti, G. (2003). Tuning engineering education into the European higher education orchestra. European Journal of Engineering Education, 28(3), 251-273.

Markes, I. (2006). A review of literature on employability skill needs in engineering. European Journal of Engineering Education, 31(6), 637-650.

Martínez Costa, C., Calvet Puig, D., Pons Peregort, O., \& Tura Solvas, M. (2007). Inserción laboral de las titulaciones de la subárea de tecnologías avanzadas de la producción. Paper presented at the International Conference on Industrial Engineering \& Industrial Management - CIO (pp. 985-992). Madrid.

Maskell, B. H. (2000). Lean Accounting for Lean Manufacturers. Manufacturing Engineering, 125(6), 46-.

Mummolo, G. (2007). The future for industrial engineers: education and research opportunities. European Journal of Engineering Education, 32(5), 587-598.

Order CIN/2134/2008 of 3 july 2008 (2008). Orden por la que se establecen los requisitos para la verificación de los títulos universitarios oficiales que habiliten para el ejercicio de la profesión de Ingeniero Técnico Industrial.

Porter, M. E. \& Kramer, M. R. (2006). Strategy and society: the link between competitive advantage and corporate social responsibility. Harvard Business Review, 84(12), 42-57.

Ratchev, S., Blackwell, R., \& Bonney, M. (2002). Design of an Industrial Management course: bringing together engineering and educational approaches. European Journal of Engineering Education, 27(1), 113-129.

Salvendy, G. (2001). Handbook of industrial Engineering. Technology and operations management. New York: John Wiley \& Sons.

Schaefer, D., Panchal, J. H., Choi, S. K., \& Mistree, F. (2008). Strategic design of engineering education for the flat world. International Journal of Engineering Education, 24(2), 274-282. 
Sheppard, S., Colby, A., Macatangay, K., \& Sullivan, W. (2006). What is engineering practice? International Journal of Engineering Education, 22(3), 429438.

Teixeira, J. C. F., Ferreira, J., Silva, D., \& Flores, P. (2007). Development of mechanical engineering curricula at the University of Minho. European Journal of Engineering Education, 32(5), 539-549.

Thompson, J. D. (1967). Organizations in action. New York: McGraw-Hill.

Vazquez-Bustelo, D. \& Avella, L. (2006). Agile manufacturing: Industrial case studies in Spain. Technovation, 26(1147-1161.

Womack, J. P. \& Jones, D. T. (1996). Lean Thinking. Banish Waste and Create Wealth in Your Corporation. New York.: Simon \& Schuster.

Yannou, B. \& Bigand, M. (2004). A curriculum of value creation and management in engineering. European Journal of Engineering Education, 29(3), 355-366.

Zandin, K. B. \& Maynard, H. B. (2005). Maynard: manual del ingeniero industrial. Mexico: MC-GRAW-HILL. license contents, please visit http://creativecommons.org/licenses/by-nc/3.0/. 